\title{
Revision of the stick insect genus Leptynia: description of new taxa, speciation mechanism and phylogeography
}

\author{
Valerio Scali ${ }^{1,2}$, Liliana Milani $^{1}$, Marco Passamonti ${ }^{1}$ \\ ${ }^{1}$ Department of Biologia Evoluzionistica Sperimentale, University of Bologna, Bologna, Italy \\ ${ }^{2}$ E-mail:valerio.scali@unibo.it
}

Key words: chromosome speciation, karyotype evolution, Leptynia annaepaulae spn., Leptynia attenuata sspn., SEM morphology

\begin{abstract}
Leptynia specimens were analyzed by karyotype analysis, mitochondrial gene sequencing and SEM of bodies and eggs. Here we describe a new species, Leptynia annaepaulae, and three subspecies of $L$. attenuata Pantel (L. attenuata attenuata, $L$. attenuata iberica, L. attenuata algarvica). The phylogeny of the genus Leptynia is congruent with a karyotype trend toward a reduction of chromosome number and the shift from the shared $\mathrm{XX} / \mathrm{X} 0$ sex chromosome formula to the unusual XX/XY one. Chromosome repatterning appears to occur ahead of genetic differentiation, following a chromosome model of cladogenesis. Chromosome and genetic differentiation, in turn, appears to precede morphological distinction, thus realizing a condition of incipient species for most of the Leptynia taxa. Actually, morphological analyses revealed that, only rarely clear cut differences exist among and between taxa, while, more often, just trends in the differentiating traits occur, since the investigated characters generally suffer from some overlapping: In this study, only the $10^{\text {th }}: 9^{\text {th }}$ ratio value and the subanal vomer appear to be diagnostic for L. annaepaulae against all other Leptynia taxa. As a consequence, the subanal vomer as well as cercus tooth features with egg chorion traits are not sharply diagnostic for the remaining co-generic taxa; however, comparisons are quite helpful in reducing uncertainties. A likely phylogeographic scenario for the genus supports that Leptynia ancestors spread from Northern Africa into Southern Spain where an ancestral taxon originated L. annaepaulae $(2 n=40 / 39, X X / X 0$, with 2 large dibrachial pairs). Later on, a northbound colonization, should have originated L. caprai $(2 \mathrm{n}=40 / 39, \mathrm{XX} / \mathrm{X} 0$, all acrocentrics), from which $L$. montana $(2 \mathrm{n}=38, \mathrm{XX} / \mathrm{X} 0)$ and $L$. attenuata $(2 \mathrm{n}=36, \mathrm{XY} / \mathrm{XX})$ originated; supporting instances of chromosome repatterning have been actually observed. In this connection we like to stress that, particularly in stick insects, androgenesis has been a preferential pathway to quickly make homozygous those odd chromosome rearrangements likely responsible for low fitness in the heterozygotes.
\end{abstract}

\section{Contents}

Introduction 25

Material and methods

\begin{tabular}{|c|c|}
\hline Results & 29 \\
\hline Discussion & \\
\hline Acknowledgements & 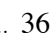 \\
\hline References .................... & 36 \\
\hline Appendix ... & \\
\hline
\end{tabular}

\section{Introduction}

According to the traditionally accepted systematics, Iberian representatives of Phasmida belong to either the family Bacillidae (Bacillus, Clonopsis) or Diapheromeridae (Leptynia, Pijnackeria), actually assigned to the different suborders of Areolatae, the former, and Anareolatae, the latter, on the basis of the presence/absence of the tiny tibial area apicalis, respectively (see Otte and Brock, 2005; Bradler, 2009). A splitting of the former genus Leptynia Bolivar into Leptynia and Pijnackeria has been implemented of recent (Scali, 2009a): Leptynia sensu novo mainly spreads into Portugal, Western and Central Spain - where it partially overlaps with the other genus -, whereas Pijnackeria ranges from Central/Eastern Spain up to Southern France (Brock, 1993). The splitting has been based on multidisciplinary approach findings, obtained from karyological, genetical and morphological investigations. The same study also allowed to settle the confused systematic status of the originally reported L. hispanica (Bolivar, 1878) and Leptynia attenuata (Pantel, 1890) species by definitively indicating Pijnackeria hispanica as type species of the new genus.

Distinct body traits differentiating specimens of the two genera appeared to be the presence/absence of the subanal vomer in the males and the abdomen tip features, including cercus morphology, in the females. In more detail, while in Leptynia males a well developed subanal vomer is always present, it is lacking in 


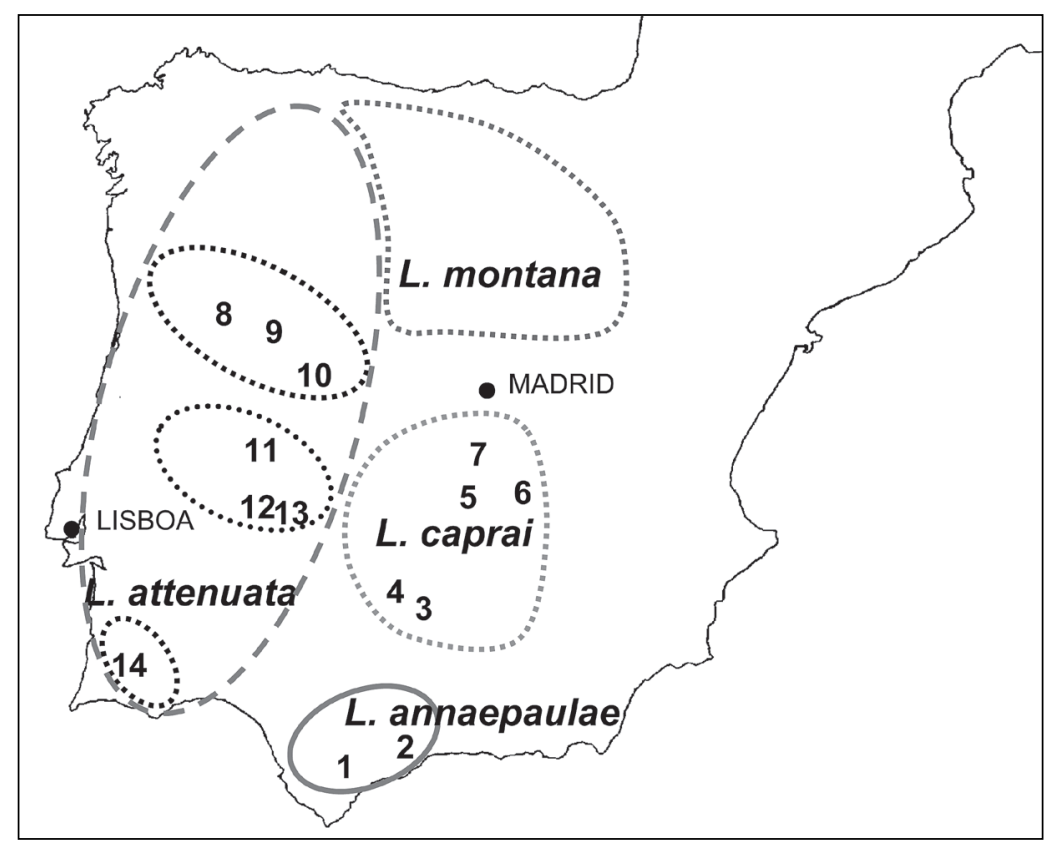

Fig. 1. Map showing the ranges of Leptynia species and subspecies. L. annaepaulae: 1) Grazalema (GRA), 2) Ojen (OJE). L. caprai: 3) Viso del Marqués (VIS), 4) San Lorenzo de Calatrava (SLC), 5) Puerto de los Majales (PLM), 6) Urda (URD), 7) Los Yébenes (LYE). L. attenuata iberica: 8) Guarda (GUA), 9) Peña de Francia (PDF), 10) Santibáñez (SIB). L. attenuata attenuata: 11) São Fiel (SFI), 12) Marvão (MAR), 13) Portalegre (POR). L. attenuata algarvica: 14$)$ Monchique (MON). All acronims are those reported in Mr Bayes tree of Fig. 2.
Pijnackeria males; at the same time, the slightly tapered and soft terminalia of Leptynia females, with back-directed protruding cerci, are sharply contrasting with the pointed, compressed and stiff last abdomen tergite, almost concealing the short, often downward directed, cerci of Pijnackeria females (Scali, 2009a). Also gross morphology of the egg, as well as its SEM chorionic pattern, proved sharply diagnostic: the dark grey egg capsule of Leptynia is remarkably thinner and smoother than that of Pijnackeria egg, which is sand coloured, thicker and all covered by an outstanding ribbon network. Furthermore, while all Pijnackeria females loosely anchor their eggs to the substrate (soil, stones), Leptynia eggs are firmly glued to the food-plant twigs.
In addition, the two genera could be well characterized through mitochondrial gene analyses, since they appeared to be neatly separated (Scali, 2009a).

Both genera encompass a few specific taxa. Leptynia species are bisexual diploids with karyotypes clearly differing for both chromosome number (40 to 36) and structure, including the sex chromosomes: the common $\mathrm{XX} / \mathrm{X} 0$ formula, for female and male respectively, is realized in the numerically highest sets $(2 \mathrm{n}=$ 40/39 and 38/37), while the unusual, clearly derived, $\mathrm{XX} / \mathrm{XY}$ in the $2 \mathrm{n}=36$ taxa. The karyotypic differences appear to be due to Robertsonian translocations (mainly fusions and inversions), which have been envisaged as a driving force of their speciation, coupled

Table 1. Collecting sites (with acronyms), sample size and chromosome number (with sex formula) of new Leptynia taxa utilized for karyology and SEM.

\begin{tabular}{|c|c|c|c|}
\hline Collecting sites & Sample size & Taxon & Chromosome number \\
\hline São Fiel (SFI), Portugal & 16 & L. attenuata attenuata Pantel, 1890 & $2 n=36(X X / X Y)$ \\
\hline Marvão (MAR), Portugal & 8 & L. attenuata attenuata Pantel, 1890 & $2 n=36(X X / X Y)$ \\
\hline Portalegre (POR), Portugal & 13 & L. attenuata attenuata Pantel, 1890 & $2 \mathrm{n}=36(\mathrm{XX} / \mathrm{XY})$ \\
\hline Guarda (GUA), Portugal & 5 & L. attenuata iberica ssp.n. & $2 n=36(X X / X Y)$ \\
\hline Peña de Francia (PDF), Spain & 8 & L. attenuata iberica ssp.n. & $2 n=36(X X / X Y)$ \\
\hline Santibañez de la S. (SIB), Spain & 28 & L. attenuata iberica ssp.n. & $2 \mathrm{n}=36(\mathrm{XX} / \mathrm{XY})$ \\
\hline Serra de Monchique (MON), Portugal & 10 & L. attenuata algarvica ssp.n. & $2 n=36(X X / X Y)$ \\
\hline Sierra de Grazalema (GRA), Spain & 31 & L. annaepaulae sp.n. & $2 n=40 / 39(X X / X 0)$ \\
\hline Ojen (OJE), Spain & 2 & L. annaepaulae n.sp. & $2 n=40 / 39(X X / X 0)$ \\
\hline
\end{tabular}


with a weak morphological differentiation (Scali, 1996; Passamonti et al., 1999, 2004).

At variance, Pijnackeria encompasses both bisexual and parthenogenetic polyploidy taxa; furthermore, the karyotypes of the bisexuals have kept a numerically invariant haploid set $(n=19)$, also very similar in structure, including sex chromosomes, to always give a $2 \mathrm{n}=38 / 37, \mathrm{XX} / \mathrm{X} 0$ chromosome complement. The polyploid parthenogens, with $3 n=57, X X X$, and $4 n=$ 76 , XXXX, apparently originated through the addition of one or two such haploid sets of 19 chromosomes, respectively. Molecular analyses have even demonstrated that those parthenogens are hybrids derived from different maternal ancestors and independent routes (Ghiselli et al., 2007).

The Leptynia taxa so far described are:

- Leptynia attenuata Pantel, 1890 (2n = 36, XX/XY), first reported from the Portuguese Castelo Branco region (Pantel, 1890). Since Pantel did not indicate the species holotype, a lectotype has been designated from his original collection housed at the Natural History Museum of Paris (Scali, 1996). Later, Leptynia attenuata had been first reported from the Algarve region in South Portugal, and initially indicated as L.attenuata tout court on the basis of cercus morphology (Scali, 1996). Afterwards, additional $L$. attenuata was recovered from the Castelo Branco region and further populations were also discovered from the Guarda and Peña de Francia areas (Passamonti et al., 2004) (see map, Fig. 1);

- L. montana Scali, 1996 (2n =37/38, X0/XX) spreads on the Sistema Central mountains, north-west of Madrid;

- L. caprai Scali, $1996(2 n=39 / 40)$, found in the hilly area south of Toledo down to the Calatrava region.

A preliminary series of bidirectional crosses suggested that among the species a considerable degree of reproductive isolation occurs with low hatching rates (from 6 to $36 \%$ ) and sterile hybrid adults (unpublished data).

Moreover, within L. attenuata three geographically distinct clades could be recognized by the cox 2 gene analysis (L. attenuata 1-3) (Passamonti et al., 2004). Although the phylogenetic inference failed to retrieve L. attenuata as a clade, the same chromosome number and unusual sex determination $(2 \mathrm{n}=36 ; \mathrm{XX} / \mathrm{XY})$ of those clades, coupled with a low reproductive isolation and a limited morphological differentiation (see below and Appendix), suggest that they should pertain to the same species. As a consequence, L. attenuata 1-3 should be better described as subspecies. The subspe- cies here defined as groups of populations with an allopatric distribution (Fig. 1) and a partial gene-flow reduction are:

- L. attenuata attenuata, the one located in the range of species' patria typica (São Fiel; Pantel, 1980);

- L. attenuata iberica, that spreading from the Portuguese region of Guarda (Serra da Estrêla) to the Spanish areas of Villablino and Peña de Francia;

- L. attenuata algarvica, spreading on the southern Portuguese Serra de Monchique (Algarve region).

Furthermore, among Leptynia samples an unnamed, sharply differentiated, basal taxon was additionally found to occur on the Sierra de Grazalema (Southern Spain); this will be here formally described as a new species, named Leptynia annaepaulae.

\section{Material and methods}

Specimens derive from a series of collecting campaigns between 2004 and 2010; derivations and composition of pertinent samples are listed in Table 1 and shown in the map (Fig. 1).

Karyotypes were obtained from mitotic plates prepared from either testes or ovariole tips after 30min fixation in Carnoy solution, teasing in $45 \%$ acetic acid, drying on a hot plate $\left(60^{\circ} \mathrm{C}\right)$ and Giemsa staining. Slides were observed in either Leica or Zeiss photomicroscopes. From 10 to 50 metaphasic plates per taxon were counted, from which karyotypes were derived; about $90 \%$ mitoses gave a constant and coherent chromosome number. In each karyotype chromosomes are arranged according their decreasing size, but also centromeric index (C.I., Levan et al., 1964), and, particularly for the small elements, the amount and shape of pericentromeric heterochromatin were taken into account. We must however admit that not always a completely sound assignment could be achieved; in this case the overall appearance of the chromosome arms guided the disposition in pairs.

The cox 2 partial sequences of 45 Leptynia specimens (GenBank Accession Numbers: AF241412/ AF241431; AF241433/AF241443; AF508800; AF508230/AF508242) where aligned with the Clustal algorithm of MEGA 3.1 (Kumar et al., 2004) and analyzed by $\mathrm{Mr}$ Bayes 3.1 (5,000,000 generations; Huelsenbeck et al., 2003), using the General Time Reversible $(\mathrm{GTR}+\mathrm{I}+\mathrm{G})$ substitution model (Lanave et al., 1984; Tavaré, 1986; Rodriguez et al., 1990), that showed the best score with Modeltest (Posada and Crandall, 1998). Pijnackeria hispanica was utilized as 


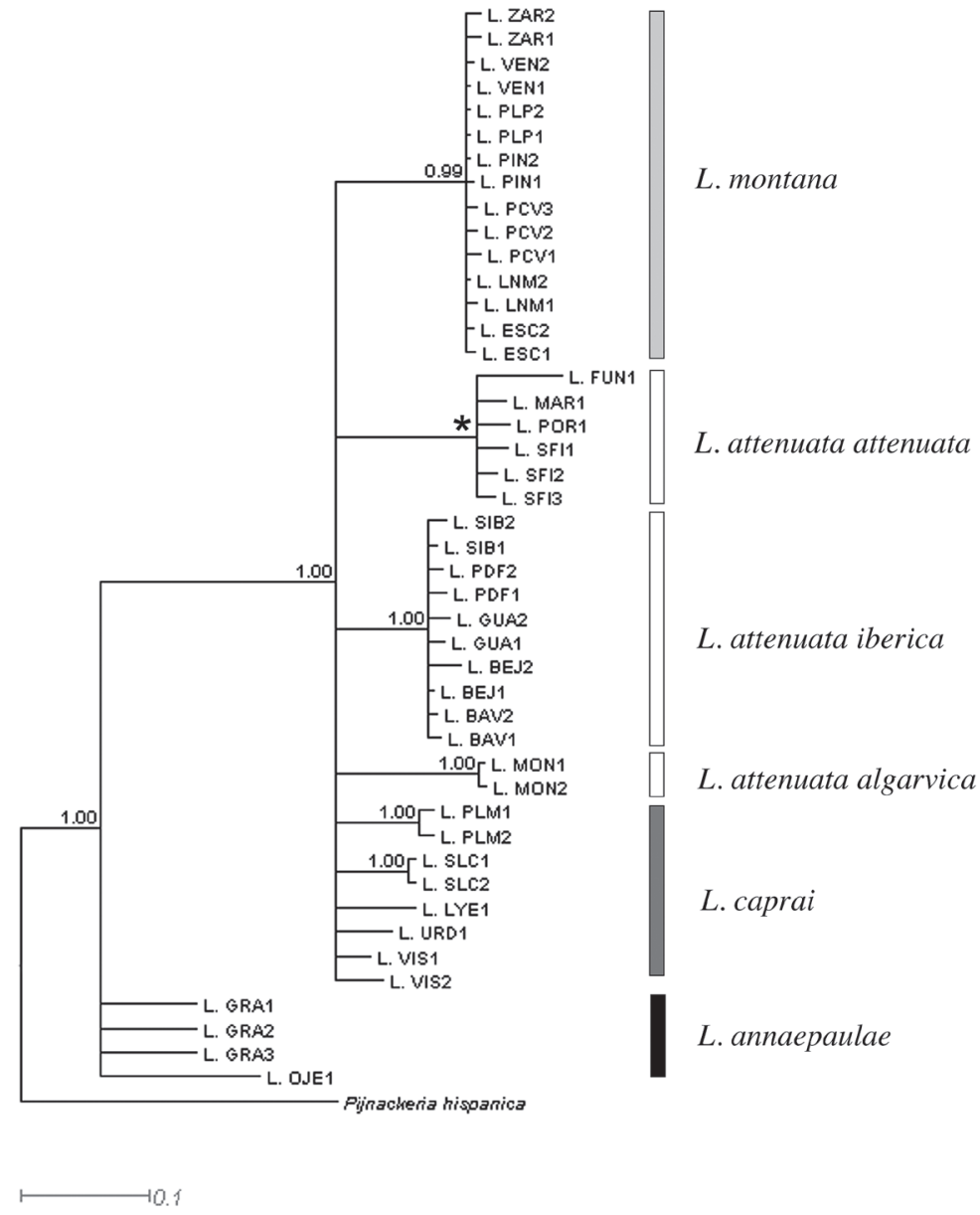

Fig. 2. Bayesian phylogenetic tree. The cox2 partial sequences of 45 Leptynia specimens were analyzed by Mr Bayes 3.1 (5,000,000 generations; Huelsenbeck et al., 2003). A clear splitting between L. annaepaulae and the other Leptynia samples ( $\mathrm{pp}=1.00)$ is apparent. The remaining Leptynia are joined in a vast unresolved polytomy, in which some well defined clades can be recognized: L. montana $(\mathrm{pp}=0.99)$, L. attenuata algarvica $(\mathrm{pp}=1.00)$, and L. attenuata iberica $(\mathrm{pp}$ $=1.00$ ). For detailed observations see the text. Pijnackeria hispanica was utilized as outgroup.

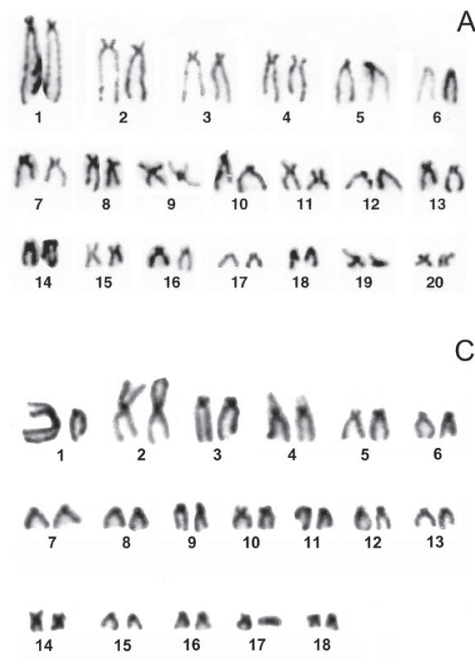

A
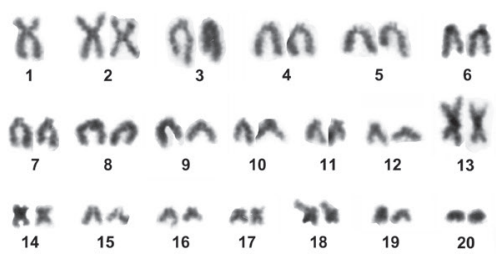

C

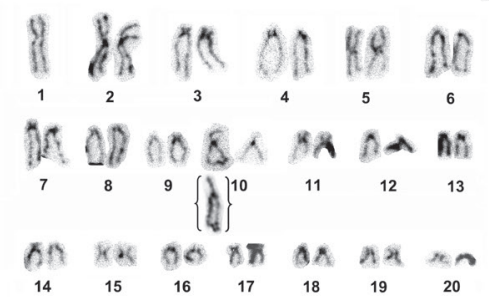

B
Fig. 3. A) Karyotype of $L$. caprai female: $2 \mathrm{n}$ $=40, \mathrm{XX} / \mathrm{X} 0$. Note the acrocentric/subacrocentric structure of all large pairs, including the $\mathrm{X}$ chromosomes (the largest). B) Karyotype of L. annaepaulae male: $2 \mathrm{n}=40, \mathrm{XX} /$ $X 0$. Note the submetacentric $X$, the $2^{\text {nd }}$ metacentric pair and the $13^{\text {th }}$ and $18^{\text {th }}$ pairs with satellites. C) Karyotype of L. attenuata attenuata male, $2 \mathrm{n}=36, \mathrm{XX} / \mathrm{XY}$, with a large submetacentric $\mathrm{X}$, and a small acrocentric $\mathrm{Y}$ ( $1^{\text {st }}$ pair). D) Karyotype of L. caprai found at Viso del Marquès: an intermediate situation between $L$. caprai and L. annaepaulae can be appreciated; furthermore a re-patterned chromosome (\# 10) can be observed. In brackets is reported the same re-patterned chromosome taken from another plate to support its maintenance in germ cells. 
outgroup (GenBank Accession Numbers: AF241444, see Fig. 2).

Scanning Electron Microscope (SEM) preparations were obtained after at least three days fixation of bodies or eggs in $70 \%$ and a complete dehydration in a graded series of ethanol solutions. An ultrasonication of 30s to eliminate, or at least significantly reduce, surface debris on specimens was then applied, which were then air dried and attached to specimen-holders with a suitable adhesive tape. Afterwards, bodies and eggs were coated with gold in a Bio-Rad SC 502 sputter-coater evaporator and observed in a Hitachi 2400 or in a Jeol JSM 5200 scanning electron microscope. The adopted terminology for body and egg descriptors is the one commonly used for stick insects (see Bradley and Galil, 1977; Scali and Mazzini, 1981). The terminology for body and egg parameters has been derived from both Clark (1976) and Milani et al. (2009). Egg and body size measures were either taken directly under a dissecting microscope or automatically evaluated by the SEM apparatus.

Both SEM and light microscope images were recorded through an electronic apparatus and then processed for publishing.

\section{Results}

Quite clearly, mitochondrial DNA genes had demonstrated that all European species of Bacillus and Clonopsis (Areolatae) and Leptynia (Anareolatae) pertain to a same monophyletic clade (Galassi, 2002); therefore the commonly accepted suborder splitting into Areolatae (represented Bacillus and Clonopsis) and Anareolatae (now represented by Leptynia and Pijnackeria) must be questioned; in this context the occurrence of the tiny area apicalis among the Phasmida (= Phasmatodea) should be considered a homoplasious (or convergent) character state, although it has been also envisaged as a homologous plesiomorphic trait (Bradler, 2009). At any rate, while further evaluation is pending, we can keep the attribution of Leptynia to the family Diapheromeridae, subfamily Pachymorphinae, tribe Gratidiini (Otte and Brock, 2005), since, after all, all morphological and structural body traits of Leptynia are coherent with the general features of those systematic groupings (see Appendix).

The karyotypes neatly separate all species, but are not diagnostic among the three $L$. attenuata subspecies (Fig. 3). It must be noted, however, that while to the same number reported for $L$. attenuata subspecies practically indistinguishable karyotypes correspond, in $L$. caprai and $L$. annaepaulae to the same score of 39/40 chromosomes consistently different karyotypes occur (Fig. 3). In this connection we want to mention that stable karyotypes have been always obtained from all analyzed specimens within each species; with one exception, however, since the karyotype of Viso del Marques specimens (Calatrava Region, southern part of $L$. caprai range) was different from the other $L$. caprai populations, and surprisingly more similar, although not identical, to that of L. annaepaulae by having a submetacentric $\mathrm{X}$ chromosome - the largest in the karyotype - and also possessing the second large metacentric pair just like L. annaepaulae, both lacking from L. caprai, whose sex chromosomes and large pairs are all acrocentrics or subacrocentrics (Fig. 3). This finding is to be confronted with the observation that the linearized NJ cox2-based tree (see Passamonti et al., 2004) put these specimens within the L. caprai cluster. The karyotype of $L$. attenuata attenuata is characterized by a large submetacentric $X$, and a small acrocentric $Y\left(1^{\text {st }}\right.$ pair). Additional outstanding pairs are the metacentric $2^{\text {nd }}$, and the acrocentric $4^{\text {th }}$ with satellites. This karyotype, with only minor differences, is also found in $L$. attenuata iberica and L.attenuata algarvica.

The Bayesian tree based on cox 2 mitochondrial gene (Fig. 2) showed a clear splitting between $L$. annaepaulae and all other Leptynia samples ( $\mathrm{pp}=1.00$ ). The remaining Leptynia are joined by a vast unresolved polytomy: L. attenuata is not retrieved as a clade, possibly due to the low variability of the cox 2 gene, but also L. caprai was not recovered as a single clade; the issue should be further investigated. However some groups can be recognized: L. montana $(\mathrm{pp}=$ $0.99)$, L. attenuata algarvica $(\mathrm{pp}=1.00)$, and L. attenuata iberica ( $\mathrm{pp}=1.00)$; on the other hand, since the $L$. attenuata attenuata clade was supported in previous analyses through Maximum Parsimony and Maximum Likelihood, based on the very same sequences (see Passamonti et al., 2004), we think we are allowed to maintain this node (here marked with an asterisk). Moreover, Fig. 4 highlights the substitutions observed in the same sequenced haplotypes of cox 2 gene: all Leptynia taxa, with the noteworthy exception of $L$. caprai, show diagnostic mutations; on the other hand, L. caprai shares several mutations with the other taxa.

On the basis of karyotype features and genetic differentiation, a corresponding morphological analysis has been carried out, by investigating most of the commonly recorded parameters of bodies and eggs (see Scali, 1996; Scali and Milani, 2009) (Table 2). 
L. montana

L. attenuata attenuata

L. attenuata iberica

L. attenuata algarvica

L. caprai

L. annaepaulae
$1111111111 \quad 1222222222 \quad 2222333333 \quad 3333334444 \quad 4444445555 \quad 5555555555 \quad 556666$ $\begin{array}{llllllll}1223366689 & 0011345667 & 8012234456 & 7789013356 & 7789990123 & 3357790112 & 2233445556 \quad 67112:\end{array}$ $5290636911581581323477025117046984356973 \quad 894036513258647316925947340584562514$ LNM1 AAGATCTTTC ACTATTTCTA TCACCCCCTC TTGAACTTTT AGTCCATTAC TCCCCTACAT ATCACTATTC TTTATC

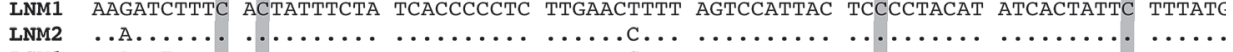

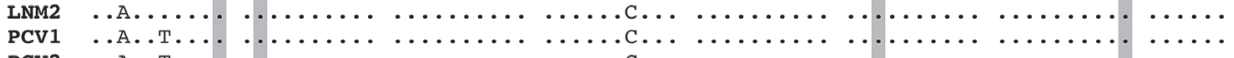
PCV2 …T...

PCV3. A......

IN1

PIN2

PIP1

PLP1

PLP2

ZAR1

ZAR2

VEN1

VEN2

ESC1

ESC2

FUN 1

1

MAR1

SFI1

SFI1

SFI3

SIB1

SIB2

PDF 1

GUA1

GUA2

BEJ 1

BEJ2

BAV1

BAV2

MON1

PLM1

PLM2

SLC1

SLC2

LYE 1

URD1

VIS 1

VIS2

OJE 1

GRA1

GRA3

.A.......

A......

A........

A..A...

A.......

A.....

.A......

A......

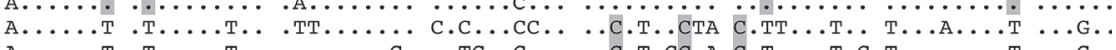

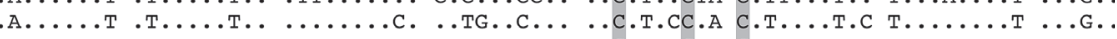

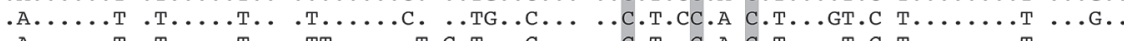

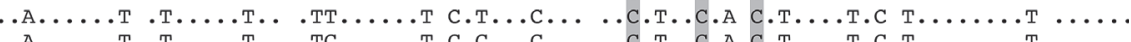

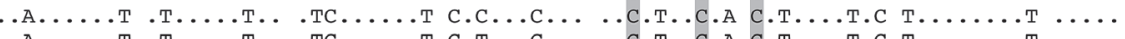

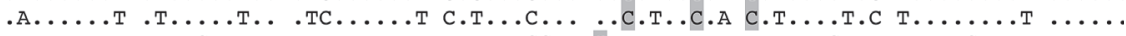

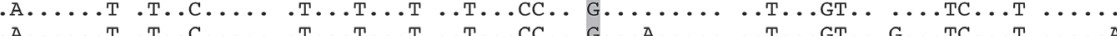

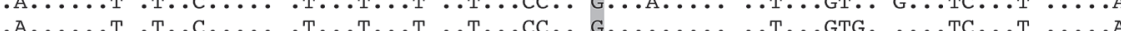

A $\mathrm{T}$ (

.

А

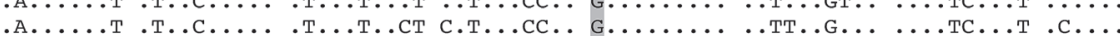

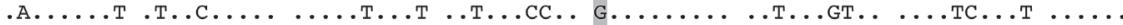

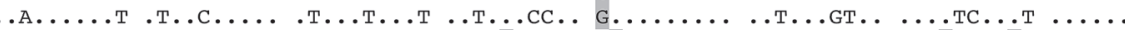

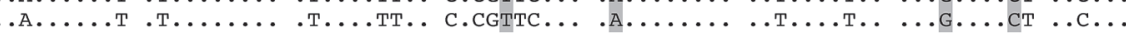

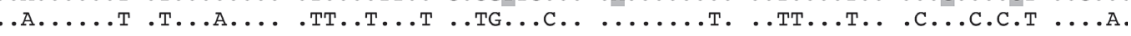

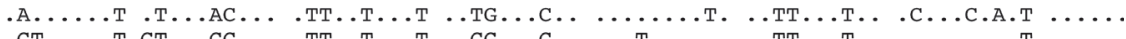

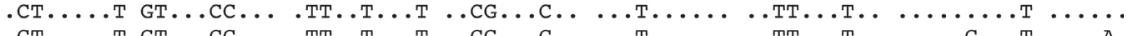

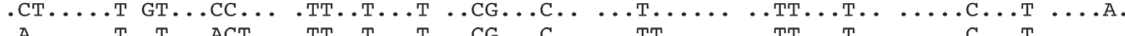

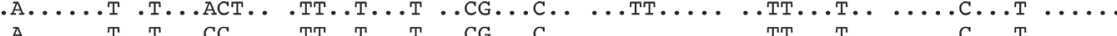

А.... . Т...СС . .

А....

TA

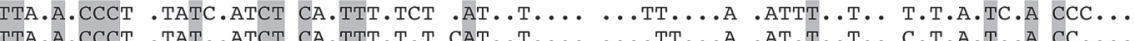

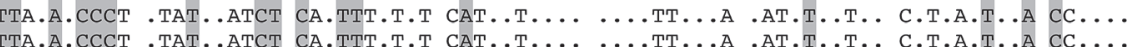

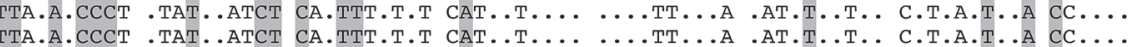

Fig. 4. Substitutions in the sequenced cox2 partial gene of Leptynia. Private mutations marked in grey. Sample acronyms as in Fig. 2. All taxa, excluding L. caprai, show diagnostic mutations. L. caprai shares several mutations with the other taxa.
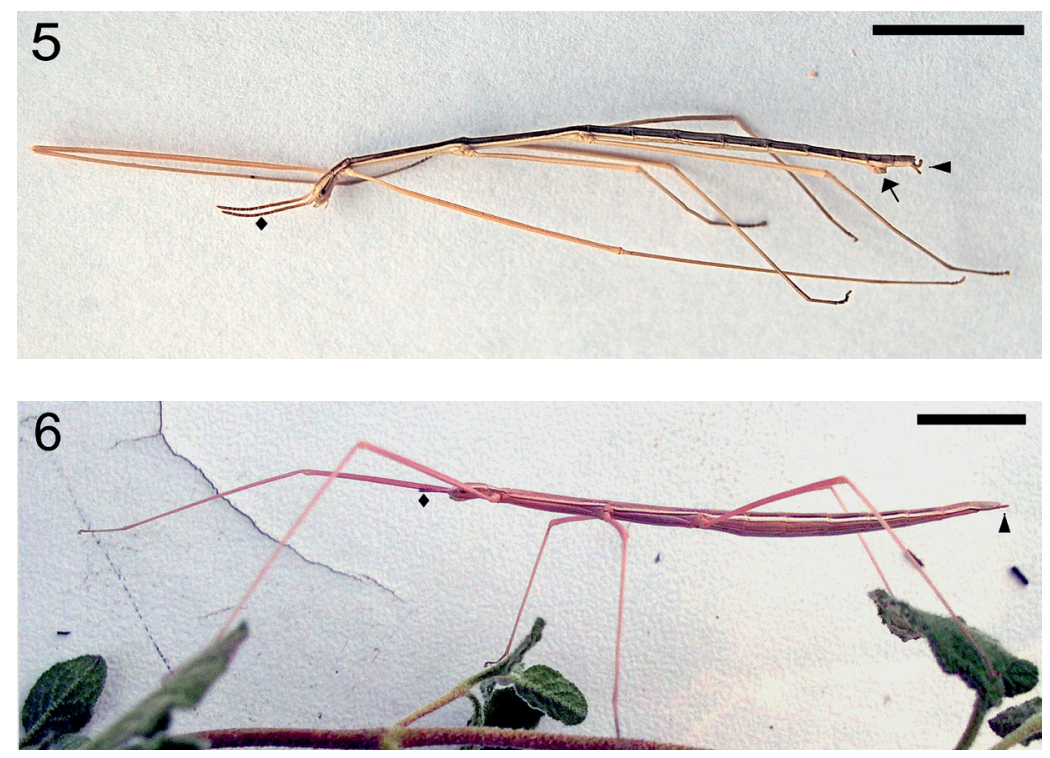

Fig. 5. Holotype (male) of Leptynia annaepaulae sp. n. Note the widespread brown pigmentation of the tergites, the sharp white line above the pleura and the canella colour of sternites. It is also possible to just see the relatively long antennae (lozenge), particularly if compared with those of the female (Fig. 6; see also Fig. 7), the profile of the subgenital operculum (arrow) and the terminal claspers (arrowhead). Bar $=1 \mathrm{~cm}$.

Fig. 6. Paratype (female) of Leptynia annaepaulae sp. n. Note the pink nuance of the whole body colour, the bright white lateral line, the short antennae (lozenge; see also Fig. 7) and the straight projecting cerci (arrowhead). $B a r=1 \mathrm{~cm}$. 
Table 2. Chromosome numbers and main body and egg parameter ranges of Leptynia taxa. Lengths are given in mm and angles in degrees. Body measures do not include antennae and cerci. The number of measured specimens are given in brackets: for $L$. caprai, $L$. montana and L. attenuata algarvica it could also include, when appropriate, those cumulatively reported in Scali (1996), amounting to about 40 for each taxon; abdom. terg. = abdominal tergite.

\begin{tabular}{|c|c|c|c|c|c|c|c|}
\hline Character & Sex & $\begin{array}{l}\text { L. attenuata } \\
\text { attenuata }\end{array}$ & $\begin{array}{l}\text { L. attenuata } \\
\text { iberica }\end{array}$ & $\begin{array}{l}\text { L. attenuata } \\
\text { algarvica }\end{array}$ & L. montana & L. caprai & L. annaepaulae \\
\hline \multirow[t]{2}{*}{ Chromosomes } & M & 36 & 36 & 36 & 37 & 39 & 39 \\
\hline & $\mathrm{F}$ & 36 & 36 & 36 & 38 & 40 & 40 \\
\hline \multirow[t]{2}{*}{ Body length } & M & $42.5-47.5(5)$ & $39.5-44.0(9)$ & $34.0-40.0(6)$ & $37.0-43.0(4)$ & $39.0-44.0(13)$ & 42.0-43.0 (3) \\
\hline & $\mathrm{F}$ & 49.5-57.0 (3) & 49.2-54.4 (9) & $46.0-50.0(4)$ & $44.0-57.0(5)$ & $44.0-55.0(7)$ & $48.0-56.0(7)$ \\
\hline \multirow[t]{2}{*}{ Antennal articles $\left(\mathrm{N}^{\circ}\right)$} & M & $15-16(10)$ & $15-18(17)$ & $14-18(12)$ & 14-18 (8) & $14-18$ (13) & $16-17(6)$ \\
\hline & $\mathrm{F}$ & $15-16(4)$ & $14-16(18)$ & $13-16(8)$ & $13-16(10)$ & $13-16(7)$ & $16-17(14)$ \\
\hline \multirow[t]{2}{*}{ Length of antennae } & M & $5.2-6.5(10)$ & $5.0-6.0(17)$ & $5.7-6.7(6)$ & $5.0-6.0(8)$ & 4.5-7.0 (13) & $6.0-7.0(6)$ \\
\hline & $\mathrm{F}$ & $3.8-4.0(4)$ & $4.0-5.0(18)$ & $3.1(2)$ & $3.5-4.5(8)$ & $3.4-4.5(5)$ & $3.5-4.2(14)$ \\
\hline \multirow[t]{2}{*}{ Mesonotum length } & M & $8.0-9.5(5)$ & $7.0-8.5(8)$ & $6.3-7.5(4)$ & $6.8-7.5(4)$ & $7.0-9.0(6)$ & $8.3-8.5(3)$ \\
\hline & $\mathrm{F}$ & $9.0-10.5(3)$ & $8.5-10.1(8)$ & $8.0(1)$ & $8.0-9.0(4)$ & $8.5-9.5(3)$ & $9.0-10.2(7)$ \\
\hline \multirow[t]{2}{*}{ Metanotum length } & M & $8.0-9.5(5)$ & $7.5-8.7(8)$ & $6.6-7.8(4)$ & $7.0-9.0(4)$ & $8.3-9.5(5)$ & $8.4-8.5(3)$ \\
\hline & $\mathrm{F}$ & $10.0-10.5(3)$ & $9.0-10.6(8)$ & $8.5(1)$ & $8.0-9.0(4)$ & $9.0-10.0(3)$ & $9.0-10.2(7)$ \\
\hline \multirow[t]{2}{*}{ Length of median femur } & M & $12.0-13.5(9)$ & $10.5-13.0(20)$ & $10.0-10.2(3)$ & $10.0-12.0(4)$ & $13.5-14.0(9)$ & $12.5-15.5(5)$ \\
\hline & $\mathrm{F}$ & $11.8-15.0(6)$ & $10.0-13.0(21)$ & $8.0-10.0(2)$ & $9.8-12.5(6)$ & $12.0-13.0(5)$ & $12.5-18.0(8)$ \\
\hline \multirow[t]{2}{*}{ Length of hind femur } & M & $15.5-18.0(9)$ & $14.5-16.5(19)$ & $12.6-14.0(5)$ & $14.0-16.0(4)$ & $15.5-17.0(5)$ & $12.5-17.0(5)$ \\
\hline & $\mathrm{F}$ & $15.8-19.0(6)$ & $12.0-17.0(21)$ & $12.0(2)$ & $12.0-16.0(4)$ & $13.5-17.0(6)$ & $14.0-18.0(8)$ \\
\hline \multirow[t]{2}{*}{ Hind femur reach } & M & $71 / 2(9)$ & $71 / 2-81 / 2(19)$ & $61 / 2-71 / 2(5)$ & $71 / 2(4)$ & $71 / 2(5)$ & $61 / 2-73 / 4(5)$ \\
\hline & $\mathrm{F}$ & $71 / 4(6)$ & $6^{1 / 2-7}(21)$ & $5 \frac{1}{2}(2)$ & $4-5(4)$ & $4-5(6)$ & $61 / 2-7(8)$ \\
\hline \multirow[t]{2}{*}{ Ratio $10^{\text {th }}: 9^{\text {th }}$ abdom. terg. } & M & $0.72-0.85(10)$ & $0.68-0.75(8)$ & $0.72-0.88(6)$ & $0.77-0.96(4)$ & $0.77-0.94(8)$ & $0.60(3)$ \\
\hline & $\mathrm{F}$ & $1.20-1.80(7)$ & $1.45-1.80(8)$ & $1.66-2.00(4)$ & $1.40-2.10(4)$ & $1.60-1.80(3)$ & $1.30-2.0(8)$ \\
\hline Egg length & & $3.5-4.5(7)$ & $3.5-4.8(6)$ & $4.1-4.8(8)$ & $3.7-4.0(8)$ & $5.7-7.2(6)$ & $5.5-5.9(8)$ \\
\hline Egg width:length ratio & & $0.24-0.32(6)$ & $0.22-0.26(10)$ & $0.22-0.23(5)$ & $0.25-0.28(8)$ & $0.13-0.19(8)$ & $0.17-0.19(8)$ \\
\hline Egg operculum angle & & $-5 /+10(6)$ & $+20 /+30(5)$ & $+15 /+20(5)$ & $+10 /+18(8)$ & $+27 /+33(6)$ & $+30(2)$ \\
\hline
\end{tabular}

Also the new Leptynia taxa are small phasmids around $40 \mathrm{~mm}$ the males and $50 \mathrm{~mm}$ the females - with the same slender body appearance as that observed in co-generic species; the common sexual dimorphism is always apparent, with males much thinner than females (Figs 5-6).

From an overview of the reported metric and meristic traits it can be seen that in the males the $10^{\text {th }}: 9^{\text {th }}$ ratio value appears to be fully diagnostic for L.annaepaulae, whereas no other sharp distinguishing trait exists to separate a given taxon from all others; rather, only morphological or dimensional trends could be observed for the analyzed traits, since the recorded features or values always suffer some overlapping (Table 2). However, additional, mainly qualitative characters - such as the subanal vomer features and cercus tooth shape/size - although rather tricky, allowed a reasonably safe diagnosis of a few Leptynia taxa (Table 3 and Appendix).

L. attenuata algarvica males are the smallest, while those of the other two L. attenuata subspecies largely overlap each other and with the remaining species. $L$. attenuata algarvica females too tend to be small, but their size range amply overlaps or even lays within those of the remaining taxa. The article number of antennae is the same in males and females of all species; however, their length is consistently higher in males than females, thus confirming the well known sexual allomorphism for this character in stick insects (Fig. 7); the very low values of antennal lengths recorded for $L$. attenuata algarvica females could be linked to their small body size, but also the reduced sample could be responsible for this finding.

One additional trait often utilized to characterize related orthopteroid taxa, independently from absolute specimens' size, is the hind femur reach when positioned parallel to the abdomen. In tested males of the already described species, the hind leg femur invariably attained about the half of the $7^{\text {th }}$ abdominal segment, thus being of no diagnostic value. The same parameter gave similar results for L. attenuata and $L$. annaepaulae males; the only finding at variance has been obtained from L. attenuata iberica: out of six 

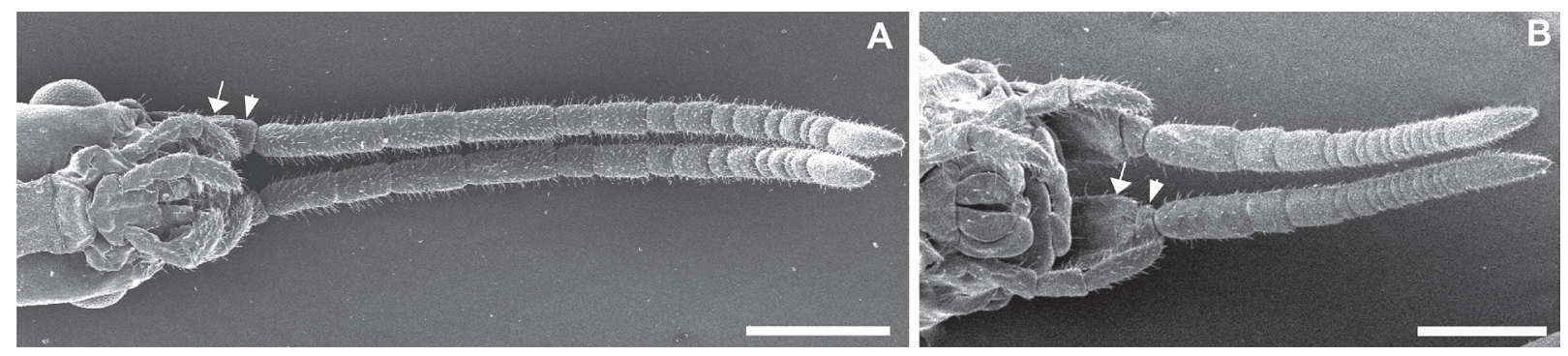

Fig. 7. A) Antennae of a Leptynia male, with 17 articles: all taxa share the same antennal structure and have a similar length range with higher values than females (sex allomorphism). Bar represents $1 \mathrm{~mm}$. B) Antennae of a Leptynia female, with 16 articles. The structural antennal plan is the same as that of males, but the single articles are shorter. Incomplete or additional segmentations can modify the basic article number in both sexes. Legend: arrow - scapus; arrowhead - pedicellus. Bar = $0.8 \mathrm{~mm}$.

measured males two had proportionately longer legs, since their femur reached almost half of the $8^{\text {th }}$ abdominal segment. A slightly more significant result has been obtained from females: the hind femur reach has been observed to increase from L. attenuata algarvica (half of the $5^{\text {th }}$ segment) to L. attenuata iberica (from $5^{\text {th }}$ to $6^{\text {th }} / 7^{\text {th }}$ segment joint) and, further, to $L$. attenuata attenuata (from the base of $7^{\text {th }}$ segment to half of it). In L. annaepaulae females the hind femur constantly reaches from half of $6^{\text {th }}$ up to $7^{\text {th }}$ segment articulation.

As already pointed out, the presence of a subanal vomer (about $1 \mathrm{~mm}$ long) is a major diagnostic character of Leptynia males, when compared to those of the related Pijnackeria genus, which lack it (Scali, 2009a, b). In addition, its shape has now turned out to realize different patterns among Leptynia species and even subspecies. As a matter of fact, the proximal part the vomer base is swollen, almost spherical, in most specimens of L. attenuata attenuata and L. attenuata algarvica; moderately swollen and only slightly wider in L. attenuata iberica, flat and decidedly wider than its following segment in L. annaepaulae, where it also shows a lobate structure (Fig. 8A, C, E). Furthermore, in many L. attenuata males the vomer may appear furrowed on the base and/or the distal, narrower part of it (Fig. 8C, E). The same observations revealed that even for the already known L.attenuata and L.caprai

Table 3. Comparisons between subanal vomer and cercus traits in Leptynia males (see Fig. 8).

\begin{tabular}{|c|c|c|}
\hline Taxon & Vomer base features & Cercus tooth features \\
\hline L. a. attenuata & swollen and wider than the vomer stem close to it & slender and of medium length (Fig. 8B) \\
\hline L. a. iberica & $\begin{array}{l}\text { moderately swollen and slightly wider than } \\
\text { the vomer stem }\end{array}$ & of intermediate thickness (wide base) and short (Fig. 8F) \\
\hline L. a. algarvica & swollen and wider than the vomer stem & thick, long and stout (Fig. 8D) \\
\hline L. montana & $\begin{array}{l}\text { moderately swollen and narrow, almost of the } \\
\text { same thickness of the vomer stem }\end{array}$ & thick and short (Scali, 1996) \\
\hline L. caprai & not swollen, narrow as the vomer stem & very thick (wide base) and very short (Scali, 1996) \\
\hline L. annaepaulae & flat, very wide with lateral lobes & slender and short (Fig. 8E) \\
\hline
\end{tabular}

Fig. 8. Sample of male and female terminalia of Leptynia, showing some significant structures. A-B) L. attenuata attenuata male: the swollen smooth subanal vomer base (1) its furrowed distal segment and the cercus (2) with a slender tooth (arrowhead); the tapered operculum (3). C-D) L. attenuata algarvica male: the vomer swollen base, the stout tooth (arrowhead) and the truncated operculum (3). E) L. annaepaulae male: the flat and lobed appearance of the vomer base (1); the short, pointed tooth (arrowhead); the posterior operculum border (3). F) L. attenuata iberica male: the low conical tooth (arrowhead), with a wide base. G) Female terminalia of $L$. attenuata attenuata showing the $1^{\text {st }}$ ovipositor valve (6) the tapered, soft $10^{\text {th }}$ sternite (7) and straight cerci (2). Legend: 1 - vomer; 2 - cercus; 3 - male operculum; 4 - $9^{\text {th }}$ abdominal tergite; 5 - 10 $0^{\text {th }}$ abdominal tergite; 6 - ovipositor valve ( $8^{\text {th }}$ abdominal sternum); 7 - $10^{\text {th }}$ sternite; arrowhead - cercus tooth. Scale bars: A, B, C, E, F = $0.5 \mathrm{~mm} ; \mathrm{D}=0.2 \mathrm{~mm} ; \mathrm{G}=1 \mathrm{~mm}$. 

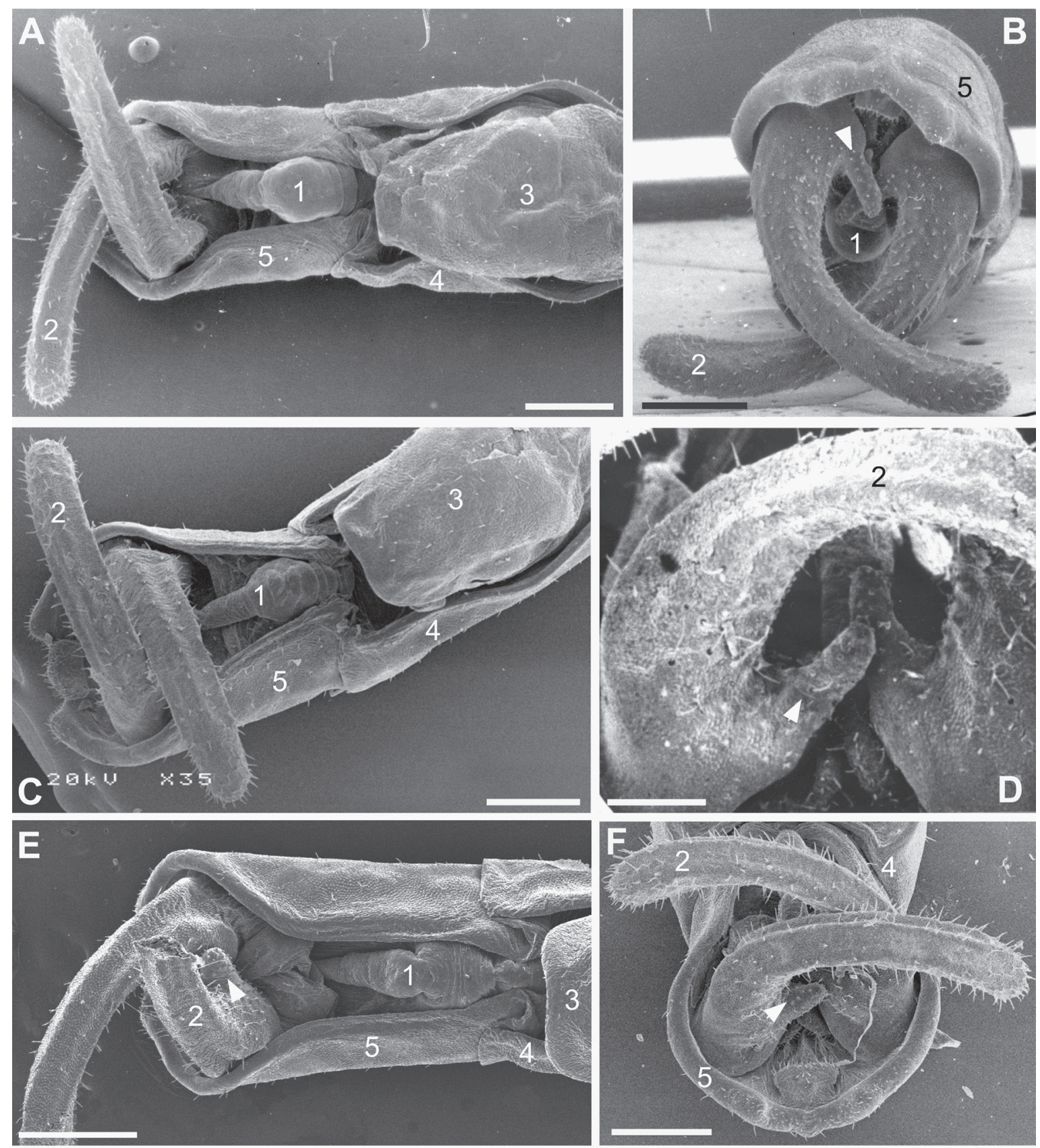

G

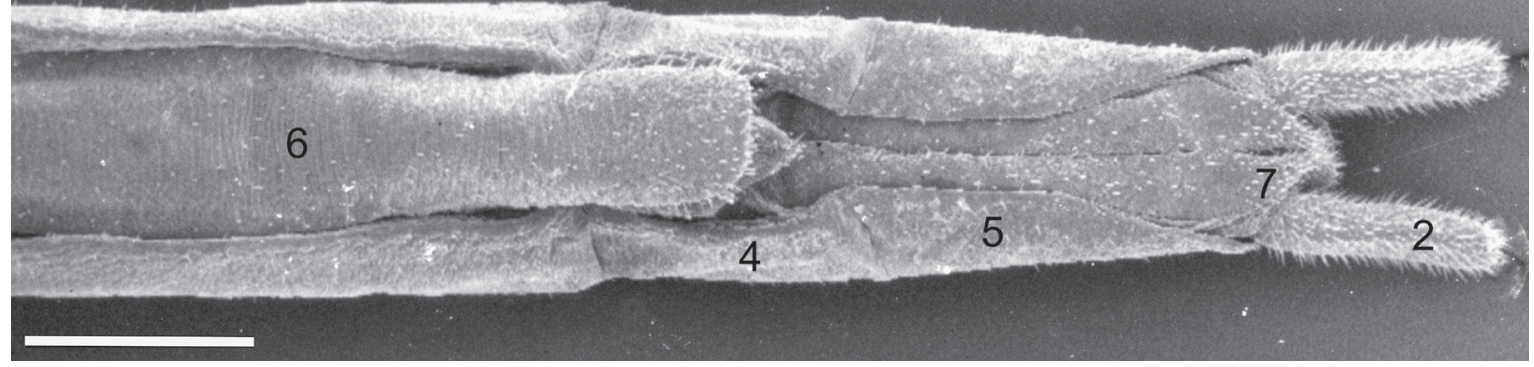


differences can be perceived, so that a complete taxon-specific series could be obtained (Table 3).

Male cerci are well developed and in the adults assume a typical conformation of claspers; a peculiar trait of Leptynia claspers is the occurrence of a projecting tooth of variable size and shape, placed near the base of each cercus. When such teeth were compared among
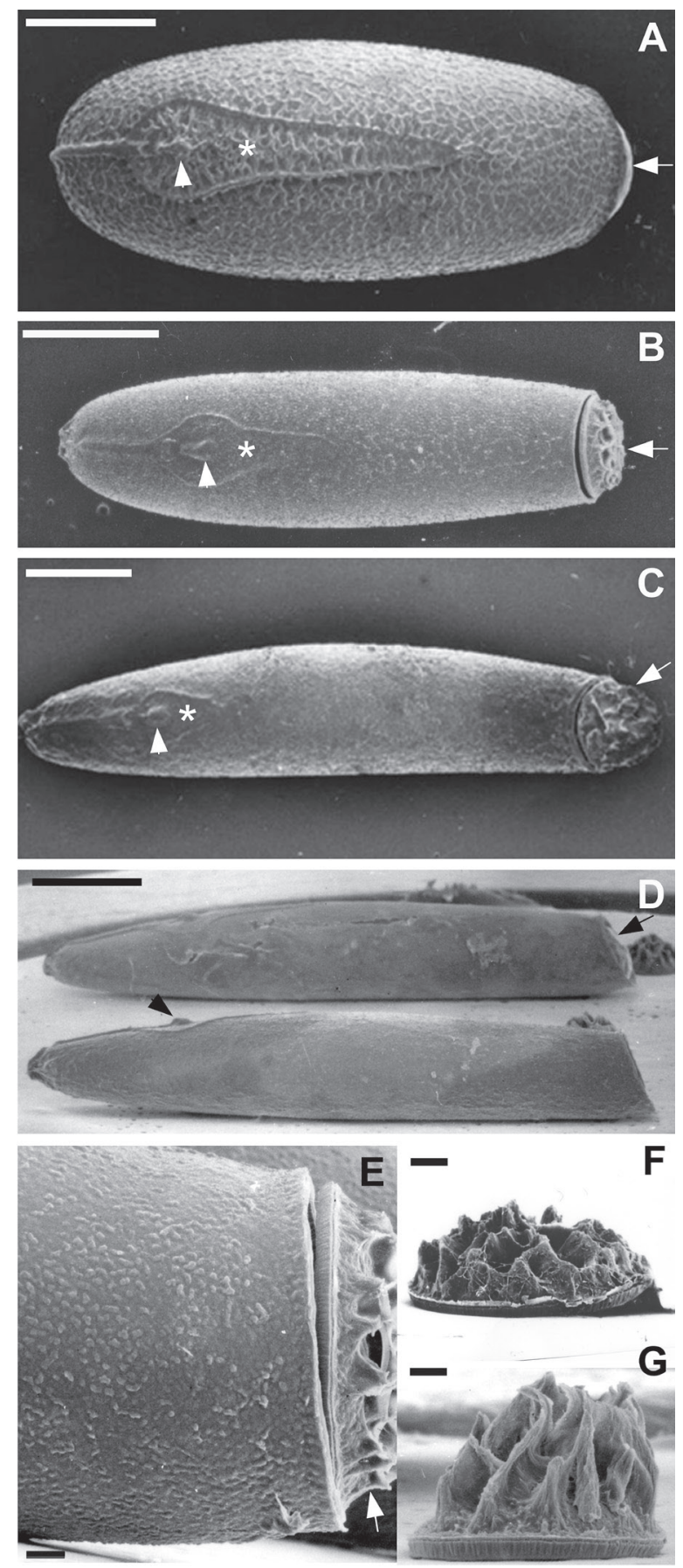

the first described species (L. caprai, L. montana and $L$. attenuata), species-specific patterns could be appreciated: it appeared very low with a wide base in L. caprai, longer and thick in L. montana, longest and stout in $L$. attenuata, so that tooth features appeared fully diagnostic (Scali, 1996). The new taxa as well show differing cercus tooth traits: slender, short and pointed in $L$. annaepaulae; slightly longer, thin with a blunt apex and obliquely inserted in L. attenuata attenuata; low, conical with a wider base in L. attenuata iberica; long and more robust in L. attenuata algarvica (Fig. 8B, D-F).

Therefore, the clear cut differences observed among the first described species have become rather subtle and careful comparisons are now needed to make a sound assessment of each taxon.

A partially diagnostic condition is found when egg size and chorion features are compared. All Leptynia species lay thin, elongated eggs, but $L$. caprai and $L$. annaepaulae appear to have comparably longer eggs than others (Table 2); accordingly L. montana and $L$. attenuata lay shorter eggs, amply overlapping each other for size range. The higher length values of $L$. caprai and $L$. annaepaulae are mainly due to their shared traits of developing both a raised polar mound and a dome-shaped operculum, while in the shortest eggs a shallow polar mound and a flat operculum are realized (Fig. 9). All this is mirrored in the width to length ratios: owing to the almost invariant egg width values in all taxa, the lowest ratio figures are found for L. caprai and L. annaepaulae, while for the remaining clearly higher values are obtained (Table 2). At the same time it can be seen that L. annaepaulae eggs, together with L. caprai, show the highest values of

Fig. 9. Eggs of Iberian phasmids. A) Dorsal view of egg capsule of Pijnackeria, showing its outstanding ribbon pattern, the micropylar area (asterisk), micropylar cup (arrowhead) and opercular opening (arrow). B) Dorsal view of the slender egg of $L$. attenuata attenuata with much lower ribbon-net developmentand a flat operculum (arrow). C) Dorsal view of the very elongated capsule of L. caprai, showing, the micropylar area (asterisk), the raised operculum (arrow) and the developed polar mound at the opposite pole. D) Side view of L. annaepaulae eggswith the positive angle of the opercular opening (right) and the raised polar mound (left). E) anterior part of L. attenuata attenuata egg with small pin's heads and an almost perpendicular operculum. F) The shallow operculum of L.attenuata algarvica. G) The dome-shaped one realized in L. caprai and L. annaepaulae. Scale bars: $1 \mathrm{~mm}$ in A-D and $0.1 \mathrm{~mm}$ in E-G. Legend: arrow, operculum; arrowhead, micropylar cup; asterisk, micropylar plate. 
positive opercular angle; the value is intermediate in $L$. montana and variable within L. attenuata, where in the nominal subspecies it can be neutral or even become negative (Fig. 9B-E). On the whole, the series of egg data sets heavily blurs the picture resulting from the early description of Leptynia species, where the opercular angles appeared to constitute fully diagnostic traits (Scali, 1996). The fine chorionic pattern on both egg capsule and the lance-tip shaped micropylar area is similar in the new taxa and is made by a carpet of irregularly shaped pin-heads (about $2 \mu \mathrm{m}$ in diameter), with a superimposed irregular pattern of sparse ribbons. These attain a maximum development and density on the roundish operculum and the polar mound, particularly in L. annaepaulae, where they may take the appearance of projecting cristae as it also occurs in L. caprai (Fig. 9).

Detailed descriptions of the new taxa and their comparative diagnosis, are given in the Appendix (Tables 4-5).

\section{Discussion}

This paper provides the formal description of Leptynia species and subspecies embodied into the recently re-defined genus (Scali, 2009a) and also makes a comprehensive comparison among them by analyzing their taxonomical features.

Leptynia species' distinction chiefly resides on karyological findings and it is supported by parallel molecular data obtained from the mitochondrial cox2 gene.

It has been suggested that the Leptynia speciation driving force has been the karyotypic differentiation entraining a certain amount of reproductive isolation and a subsequent genetic differentiation (Passamonti et al., 2004; Ghiselli et al., 2007). On the whole, these observations appear to support that the chromosomal changes occur ahead of genetic differentiation of taxa and these, in turn, precede their morphological characterization. As a matter of fact, nowadays the morphological characterization process rather provides an intricate mosaic of partially diagnostic traits: owing to these new findings even the cercus tooth and egg features, which appeared to be sharply diagnostic traits (Scali, 1996), actually realize a series of characters with faint boundaries, if the whole range of taxa has to be considered; at present, they just give hints to the right classification. As far as our records now tell, only the $10^{\text {th }}: 9^{\text {th }}$ tergite ratio and the vomer traits of $L$. an- naepaulae are unambiguously identifying the species against all other Leptynia. On the whole, Leptynia taxa seem to realize a condition of incipient morphological differentiation, whereas karyotype and genetic differentiations have been already built. It is in this kind of incomplete morphological information that multidisciplinary approaches to taxon definition appear of paramount utility.

The comprehensive phylogenetic relationships suggested by chromosomal and molecular data sets are congruent with the karyotype trend toward a numerical reduction of chromosomes and, at the same time, support the view that L. annaepaulae can be considered the outcome of an older cladogenetic event, while L. caprai, L. montana and L. attenuata could derive from the same genetic pool on a more recent time. From the cox 2 mutation pattern and phylogenetic reconstruction, L. caprai might be deemed as representative of the ancient gene pool from which L. montana and L. attenuata arose. Moreover, L. caprai should be considered as an assembly of populations sharing the same chromosome number, but different karyotype morphologies. This finding is supported by the observation that the Viso del Marquès specimens are karyologically similar to L. annaepaulae although genetically close to L. caprai; in addition the occurrence of clearly translocated chromosomes is supporting their inferred important role in Leptynia cladogenesis. In our opinion Viso del Marquès could be an incipient separate species, but, for the limited set of observations due to very small sample available, we prefer not to formally define the issue.

If we now integrate these assumptions with the actual distribution of taxa, we may suggest the following phylogeographic scenario for the genus: it is unanimously accepted that stick insect are tropical and subtropical in origin; therefore Leptynia ancestors should be originated in Africa, where also other Leptynia have been provisionally recorded (Bradley and Galil, 1977), and spread into Southern Spain through the Gibraltar Straits. In the Iberian Peninsula an ancestral taxon, with a numerically high karyotype (around 40 chromosomes) should have originated L. annaepaulae, restricted to the southern range of Leptynia. Later on, a northern colonization, paralleled by Robertsonian translocations and inversions, could have originated L. caprai, from which L. montana and L. attenuata arose. While molecular data sets clearly support L. montana, this is not clearly so for L.attenuata, notwithstanding that the shared rare XY male sex-formula appears to constitute a good 
synapomorphy. For this reason, we cautiously take $L$. attenuata as a unique species, and the three groups as subspecies.

Karyotype repatterning, repeatedly invoked above as a triggering cladogenetic event, has been much questioned mainly in view of the theoretical difficulties in the fixation of chromosome rearrangements, responsible for a low fitness in the heterozygotes. In addition to the various hypotheses put forwards to overcome such limitation (see Riesenberg, 2001), we would like to recall here the one envisaging androgenesis as a preferential pathway to quickly making homozygous odd chromosome rearrangements, particularly in stick insects (Passamonti et al., 2004). As a matter of fact, the all-paternal nuclear inheritance of androgens allows the embryo to immediately duplicate the heterozygous chromosome novelties, as it has been first witnessed in Bacillus and, of recent, in Clonopsis stick insects (Mantovani and Scali, 1992; Tinti and Scali, 1996; Milani et al., 2009, 2010; Scali, 2009b; Scali and Milani, 2009). Androgenesis is also shared by the whole fresh-water bivalve genus Corbicula (Komaru et al., 1998; Byrne et al., 2000; Qiu et al., 2001) and even by the Saharan cypress Cupressus dupreziana (Pichot et al., 2001). Actually, the peculiar cytological features of androgenesis appear to easily overcome the major genetic and evolutionary constraints believed to be entrained by the heterozygous condition of freshly repatterned karyotypes.

\section{Acknowledgements}

We thank Mrs Luciana Scali for her patient and skilful help in specimens' collecting. We want also to acknowledge the financial support of the Canziani bequest and the punctual observations by very skilful reviewers, which considerably contributed to improve the paper clarity.

\section{References}

Bianchi AP. 1992. Karyological studies of Mediterranean stickinsects belonging to the genera Clonopsis and Leptynia (Insecta Phasmatodea). Caryologia 45: 1-19.

Bianchi AP, Meliado P. 1998. Analysis of the karyotypes of four species of the Leptynia attenuata complex (Insecta Phasmatodea). Caryologia 51: 207-219.

Bolivar I. 1878. Analecta Orthopterologica. Anales de la Societad Española de Historia Natural 4: 423-424.

Bradler S. 2009. Die Phylogenie der Stab- und Gespenstschrecken (Insecta: Phasmatodea). Species, Phylogeny and Evolution 2: 3-139.
Bradley JC, Galil BS. 1977. The taxonomic arrangement of the Phasmatodea with keys to subfamilies and tribes. Proceedings of the Entomological Society of Washington 79: 176-208.

Brock PD. 1993. Studies on stick insects of the genus Leptynia in Spain. Amateur Entomologist's Society Bulletin 52: 165172.

Brock PD. 2011. Phasmida Species File Online. Available via http: //Phasmida.SpeciesFile.org [accessed 30 Oct. 2011].

Brunner von Wattenwil K. 1893. Revision du systéme des Orthoptères et Description des espèces rapportées par M. Leonardo Fea de Birmanie. Annali del Museo Civico di Storia Naturale Giacomo Doria. Genova.

Byrne M, Phelps H, Church T, Adair V, Selvakumaraswamy P, Potts J. 2000. Reproduction and development of the freshwater clam Corbicula australis in southeast Australia. Hydrobiologia 418: 185-197.

Clark JT. 1976. The eggs of stick insects (Phasmida): A review with a description of the eggs of eleven species. Systematic Entomology 1: 95-105.

Galassi A. 2002. Rapporti filogenetici nei Phasmatodea (Arthropoda Insecta): dati immunocitochimici, cromosomici e molecolari. PhD-thesis, University of Bologna.

Ghiselli F, Milani L, Scali V, Passamonti M. 2007. The Leptynia hispanica species complex (Insecta Phasmida): Polyploidy, parthenogenesis, hybridization and more. Molecular Ecology 16: 4256-4268.

Günther K. 1953. Uber die taxonomische Gliederung und die geographische Verbreitung der Insectenordnung der Phasmatodea. Beitrage Entomologie 3: 541-568.

Huelsenbeck JP, Ronquist F. 2003. MrBayes 3: Bayesian phylogenetic inference under mixed models. Bioinformatics 19: $1572-1574$

Kirby WF. 1904. A synonymic Catalogue of Orthoptera. I. Phasmidae. London. Pp. 317-423.

Komaru A, Kawagishi T, Konishi K. 1998. Cytological evidences of spontaneous androgenesis in the freshwater clam Corbicula leana prime. Development Genes Evolution 208: 46-50.

Kumar S, Tamura K, Nei M. 2004. MEGA3: integrated software for molecular evolutionary genetics analysis and sequence alignment. Brief Bioinform 5: 150-163.

Lanave C, Preparata G, Saccone C, Serio G. 1984. A new method for calculating evolutionary substitution rates. Journal Molecular Evolution 20: 86-93.

Levan A, Fredga K, Sandberg AA. 1964. Nomenclture for centromeric position on chromosomes. Hereditas 52: 201-220.

Mantovani B, Scali V. 1992. Hybridogenesis and androgenesis in the stick-insect Bacillus rossius-grandii benazzii (Insecta Phasmatodea). Evolution 46: 783-796.

Milani L, Scali V, Passamonti M. 2009. The Clonopsis gallica puzzle: Mendelian species, polyploid parthenogens with karyotype re-diploidisation and clonal androgens in Moroccan stick insects. Journal of Zoological Systematics and Evolutionary Research 47: 132-140.

Milani L, Ghiselli F, Pellecchia M, Scali V, Passamonti M. 2010. Reticulate evolution in stick insects: the case of Clonopsis (Insecta Phasmida). BMC Evolutionary Biology 10: 258-272.

Otte D, Brock PD. 2005. Phasmida Species File. Catalogue of the stick and leaf insects of the world. 2nd ed. Philadelphia: The Insect Diversity Association at the Academy of Natural Sciences. 
Pantel PJ. 1890. Notes Orthoptérologiques. II Les Phasmides d'Europe et des pays limitrophes. Anales de la Sociedad Española de Historia Natural 19: 371-404.

Passamonti M, Mantovani B, Scali V. 1999. Karyotype and allozyme characterization of the Iberian Leptynia attenuata species complex (Insecta Phasmatodea). Zoological Science 16: 675-684.

Passamonti M, Mantovani B, Scali V. 2004. Phylogeny and karyotype evolution of the Iberian Leptynia attenuata species complex (Insecta Phasmatodea). Molecular Phylogenetics and Evolution 30: 87-96.

Pichot C, El Maâtaoui M, Raddi S, Raddi P. 2001. Surrogate mother for endangered Cupressus. Nature 412: 39.

Posada D, Crandall KA. 1998. Modeltest: testing the model of DNA substitution. Bioinformatics 14: 817-818.

Qiu A, Shi A, Komaru A. 2001. Yellow and brown shell color morphs of Corbicula fluminea (Bivalvia: Corbiculidae) from Sichuan Province, China, are triploids and tetraploids. Journal Shellfish Research 20: 323-328.

Riesenberg LH. 2001. Chromosomal rearrangements and speciation. Trends in Ecology and Evolution 16: 351-358.

Rodríguez F, Oliver JL, Marín A, Medina JR. 1990. The general stochastic model of nucleotide substitution. Journal of Theoretical Biology 142: 485-501.

Scali V. 1996. Descrizione di due specie incipienti di insetti stecco (Phasmatodea) del complesso Leptynia attenuata Pantel: L.montana n. sp. e L. caprai n. sp. Redia 79: 123-136.

Scali V. 2009a. Revision of the Iberian stick insect genus Leptynia Pantel and description of the new genus Pijnackeria. Italian Journal of Zoology 76: 1-11.
Scali V. 2009b. Metasexual stick insects: model pathways to losing sex and bringing it back. Pp. 317-345 in: I Schön, K Martens, PV Dijk, eds, Lost sex. Dordrecht: Springer.

Scali V, Milani L. 2009. New Clonopsis stick insects from Morocco: The amphigonic $C$. felicitatis sp.n., the parthenogenetic $C$. soumiae sp.n., and two androgenetic taxa. Italian Journal of Zoology 76: 291-305.

Scali V, Mazzini M. 1981. The eggs of stick insects Sipyloidea sipylus (Westwood) and Orxines macklotti De Haan (Phasmatodea, Heteronemiidae): a scanning electron microscopic study. International Journal of Invertebrate Reproduction 4: 25-38.

Tavaré S. 1986. Some probabilistic and statistical problems on the analysis of DNA sequences. Lectures on Mathematics in the Life Sciences 17: 57-86.

Tinti F, Scali V. 1996. Androgenetics and triploids from an interacting parthenogenetic hybrid and its ancestors in stick insects. Evolution 50: 1251-1258.

Zompro O. 2004. Revision of the genera of the Areolatae, including the status of Timema and Agathemera (Insecta, Phasmatodea). Verhandlungen des Naturwissenschaftlichen Vereins in Hamburg (NF)37: 1-327.

Received: 23 March 2011

Revised and accepted: 2 December 2011

Published online: 31 January 2012

Editor: J.A. Miller 


\section{Appendix}

Systematics of the genus Leptynia and descriptions of new taxa

All taxa of the genus have a slender body, typical of most stick insects. They are also characterized by the absence of wings, have only compound eyes without ocelli and show a prognathous head with a well developed gula. The comprehensive cladistic phylogenetic analysis of Phasmatodea by Bradler (2009) fully supports their monophyletic status, but also deeply upsets the traditionally accepted definition and composition of taxa as defined by Bradley and Galil (1977), because most of the groupings turned out to be polyphyletic. However, since the Bradler's proposal to transfer most Families to a new single Family 'Neophasmatidae' is controversial (see Brock, 2011; Zompro, 2004), we here maintain the traditional taxonomy of Phasmatodea (Bradley and Galil, 1977), and the formal systematic of Leptynia is summarized accordingly.

\section{Systematic account}

Family Diapheromeridae Kirby, 1904

Subfamily Pachymorphinae Brunner, 1893

Tribe Gratidiini Gunther, 1953

Genus Leptynia Pantel, 1890

The family Diapheromeridae embodies anareolate stick insects, namely lacking of area apicalis (see Introduction), with distinctly segmented antennae. Insects of the subfamily Pachymorphinae have articulated antennae shorter than fore femora, as well as smooth ventral edges of hind femora. To tribe Gratidiini belong stick insects with the anal segment truncate or slightly emarginated in the males, while variable in the females. Their $2^{\text {nd }}$ abdominal segment is at least $2 \mathrm{x}$ longer than wide. Middle and hind femora are unarmed (or rarely spinulose); cerci may be elongated but never lobed. Their distribution is very wide being found in Africa, Madagascar, Central Asia, China and Southern Europe. The genus Leptynia is an Iberian genus characterized by male antennae with a larger than long scapus. From the originally described genus, the Spanish taxa whose males lack the subanal vomer and females show a compressed abdomen tip (see Introduction) have been separated and put in the new genus Pijnackeria (Scali, 2009a). On the other hand, the reshaped Leptynia encompasses only diploid sexual species, with a well developed subanal vomer in the males and a soft, tapered, abdominal tip in the females.

Updated definition of specific and infraspecific taxa

Leptynia attenuata Pantel, 1890, subdivided into 3 subspecies, namely: Leptynia attenuata attenuata subsp. n., Pantel, 1890; Leptynia attenuata iberica subsp. n., Scali, Milani, Passamonti, 2012; Leptynia attenuata algarvica subsp. n., Scali, Milani, Passamonti, 2012.

Leptynia caprai Scali, 1996;

Leptynia montana Scali, 1996;

Leptynia annaepaulae sp. n., Scali, Milani, Passamonti, 2012.

All holotypes and the paratype have been deposited in the Museo dell'Evoluzione of Bologna University.

Body colouration of L.attenuata subspecies and of L. annaepaulae is much the same as that of the already known co-generic species (L. montana and L. caprai), for both colour shadows and pattern (Figs 5-6). Males are painted by brown stripes on the head vertex and genae; a median patch is normally found on the pronotum and deep brown stripes run along the thoracic and abdominal tergites, paralleled by a sharp white line above the pleura. Beside the brown coloured areas a light canella ground colour is found; the ground canella colour of males assumes greenish nuances on both dorsal and ventral areas, so that the lighter areas give the males an overall brown and light-green shade. Females are uniformly canella or bright-green all over the body, but genae and pleurae show a brilliant white stripe along both thoracic and abdominal segments (Fig. 6).

On the mesonotum, metanotum and last abdominal tergites of L.attenuata specimens of both sexes a faint median carina is generally present, although the thoracic carina may fade out in L. attenuata iberica and L. attenuata algarvica; L. annaepaulae lacks median carina in males; only the $10^{\text {th }}$ abdominal tergite may show it. The rim of the anal tergite of males is variably incised and appears to follow subspecific trends: the notching is generally shallow in L. annaepaulae and L. attenuata subspecies, excepting L. attenuata iberi$c a$, whose $10^{\text {th }}$ tergite incision is somewhat deeper; the shallow type of emargination closely reminds that of L. montana, whereas the second one, that of L. caprai. In females, beyond the round, often lightly notched 
posterior rim of the $10^{\text {th }}$ tergite, the supra-anal valve can be perceived.

Excepting legs and cerci, males and females of $L$. annaepaulae and $L$. attenuata subspecies are uniformly covered by very minute hemispheres (about $1 \mu \mathrm{m})$. Males are glabrous excepting for cerci and last abdominal tergites, while females show diffuse short hairs, which become denser and black on the abdomen tip (Fig. 8G).

A peculiar trait shared by Leptynia females is a series of regularly spaced teeth (likely sensorial organs) along the lateral border of the meso- and metanotum, just above the pleura, on each body side. This thoracic crenation had not been reported in the already described Leptynia taxa.

Males of L. annaepaulae and all L. attenuata subspecies show muticous fore legs, whereas the mid and hind pairs may develop few (1-5) very small teeth; in females all leg pairs may similarly show few small teeth; this condition also occurs in the already described species of the genus. The shape and size of the subgenital operculum do not reveal taxon specific characters, always being dome shaped with a roundish, lightly undulated posterior rim just approaching the $9^{\text {th }} / 10^{\text {th }}$ sternite articulation (Fig. $8 \mathrm{~A}, \mathrm{C}, \mathrm{E}$ ).

All Leptynia females share a very similar general morphology, particularly for their short antennae and leg segments. Also female terminalia, are very uniform throughout the genus, since, in addition to the gently tapered and soft tip, with straight protruding cerci, are also invariably characterized by the inferior ovipositor valve with a narrowing distal third, only approaching the $9^{\text {th }} 10^{\text {th }}$ sternite articulation, and allowing the $1^{\text {st }}$ and $2^{\text {nd }}$ valve pairs to be seen (Fig. 8G). At any rate, all these features sharply differ from those of the Pijnackeria female terminalia, that are characterized by a paddle-shaped subgenital valve tip, ending beyond the $9^{\text {th }} / 10^{\text {th }}$ sternite boundary and completely concealing the other ovipositor valves. Also, in $\mathrm{Pi}$ jnackeria females cerci are almost completely hidden by the pointed abdomen tip (Scali, 2009a).

\section{Leptynia attenuata attenuata, Pantel 1890, new rank}

The subspecies embodies specimens collected primarily in the patria typica of São Fiel (Castelo Branco, Portugal) as indicated by Pantel (1890) in his seminal paper, as well as samples collected in nearby locations (see map, Fig. 1; Table 1), shown to cluster together by molecular analyses (Passamonti et al., 2004). Its definition resides on the genetic distances and the likely phy- letic relationships, based on the mitochondrial cox2 gene (Fig. 2) and allozyme data, respectively. Its karyotype obviously fits in L. attenuata for number, general structure and sex-chromosome formula $(2 \mathrm{n}=36, \mathrm{XX} /$ XY; Fig. 3C); its fine structural differentiation from the karyotype of the two new subspecies is not a sound one.

From size ranges of both males and females it can be seen that L. attenuata attenuata specimens are among the largest of the species.

Male terminalia present two traits worth mentioning: the swollen base of the subanal vomer and its common peculiar narrowings subdividing it into threefour parts; however, these traits are not subspecific diagnostic features being also shared by the other two:

- An apparently sounder characterizing trait is given by the small tooth projecting from the base of the cercus arm: the tooth (about $0.3 \mathrm{~mm}$ long) is here slender, almost cylindrical with a blunt apex (Fig. 8B).

- No peculiar features have been observed in the females; however, the subspecies appears to be characterized by the lowest egg operculum angle recorded among Leptynia taxa (Table 2), its egg capsule being cut almost perpendicularly by the opercular opening (Fig. 9E).

- Owing to the above described morphological traits, we choose a male as reference specimen from Portalegre, whose main parameters are recorded in Table 4. From the direct inspection of the reference male we can see that its left foreleg is missing and that its general colouration is deep brown. The compound, hemispherical eyes are uniformly tinged by a deep brown pigment; beyond the eye the brown pigment draws two stripes on each side of the head, the higher being larger. From the head vertex a narrow median brown line starts to continue also on the thoracic and abdominal tergites. On each side the median line is encircled by a brown patch on the pronotum and paralleled by a thick brown stripe along the thoracic and abdominal tergites. The whole ventral side and the dorsal areas free from the brown pigment, are of a light canella colour.

- As in most L. attenuata specimens a subtle but neat median carina is noticeable on the meso- and meta-notum; a similar carina is also found on the anal, $10^{\text {th }}$, abdominal tergite, which, as mentioned above, even shows a wide, shallow incision (Fig. 8B). The ventral side of the male terminalia bears the most characteristic traits of the subspecies, since the subanal vomer possesses a characteristic swollen base and the cerci a typical slender tooth of appropriate size for the subspecies (Fig. 8A-B). 
Derivatio nominis. The indication of the subspecies directly derives from the nomenclature rules, because its populations just occupy the area from which the species L. attenuata was first described by Pantel (1890).

\section{Leptynia attenuata iberica subsp. $\mathrm{n}$.}

The specimens of this taxon come from both the northern Portuguese areas of Guarda (Serra da Estrêla) and the Spanish locations on the Sierra de Peña de Francia (see map, Fig. 1; Table 1). Its definition resides on the genetic distances and the likely phyletic relationships based on the mitochondrial cox 2 gene and allozyme data, respectively (see also Passamonti et al., 2004). Its karyotype too fits in the L. attenuata for number, structure and sex-chromosome formula $(2 \mathrm{n}=$ 36, XX/XY) (Passamonti et al., 1999); its structural differentiation is too weak to be diagnostic.

Both male and female size is, on average, just smaller than those of L. attenuata attenuata, but larger than that of L.attenuata algarvica. Its morphological characterization is widely incomplete being actually limited to the shape of the subanal vomer base and cercus tooth.

From the direct inspection of the holotype and making reference to Table 4 , we can observe that its colouration is mainly brown on the tergites and cinnamon on the sternites, while the eye has a blackish tinge, deeper in the posterior half. The colour distribution pattern is the one shared by most $L$. attenuata specimens, but the two retroocular stripes on the genae run very close each other and the two dorsal stripes are so wide to fuse on the median line over the whole body length; as usual, each brown stripe is externally accompanied by a white narrow line. As already pointed out for the other Leptynia taxa, the meso- and metanotum bear a faint median carina, which is also found on the anal tergite.

Derivatio nominis. The subspecies is up to now the only one found to spread in both Portuguese (Guarda area) and Spanish (Peña de Francia and, further north, west of Villablino) locations in the central Iberian peninsula; this geographical feature has suggested us the denomination.

\section{Leptynia attenuata algarvica subsp. $\mathrm{n}$.}

The third subspecies has been found in an isolated narrow area of Southern Portugal (Algarve region) subdivided into small populations on the Serra de Mon- chique, on the rare patches of surviving wild bush vegetation. This subspecies had been referred as the nominal species Leptynia attenuata (Scali, 1996) before the re-discovery of Leptynia samples in the patria typica of São Fiel (Castelo Branco). Later on the southern Monchique populations turned out to be genetically well differentiated from the nominal ones, and therefore had to be treated as a separate taxon. A general characterizing trait of the latter is the very small size of males with comparative short hind femurs, although with relatively long antennae; correspondingly also the females are the smallest (Tables 2-3). The vomer shape with its swollen base and the long stout cercus tooth also appear characterizing traits (Fig. 8C-D). Furthermore, a limited series of crosses (3) of this subspecies with the nominal one, gave a suggestion of a low fecundity (21\% egg hatching), with even a hint of sex-ratio unbalance (7 males, no females) (unpublished data).

From the male holotype inspection it can be seen that the brown colouration in addition to the lateral parts of the tergites also marks the median line along the whole body; on the thorax the usually separate and parallel running stripes are so wide to actually fuse each other on the median line. In this subspecies some males may present an uninterrupted brown median line on the sternites of the whole body, as it occurs in the holotype, while in others only short brown segments can be observed.

Derivato nominis. Owing to its very limited range, apparently restricted to the Algarve region, we thought that this geographic feature would be adequate for the taxon.

\section{Leptynia annaepaulae sp. n. (Figs 5-6)}

The new species has been localized in the Ronda district (Sierra de Grazalema), where it colonizes small patches of shrubs and grasses (Genista, Cystus, Ru$b u s)$. This is a genetically and chromosomally well differentiated taxon (Figs 2-4), long waiting its formal description (Bianchi, 1992; Bianchi and Meliado, 1998; Passamonti et al., 2004).

While males are very much alike those of the remaining taxa for pigmentation shadows and pattern (Fig. 5), females show a peculiar light-pink nuance (Fig. 6). A morphological distinguishing trait is the very short $10^{\text {th }}$, anal tergite of males which exhibits the lowest ratio value versus the $9^{\text {th }}$ one (Table 2). On the other hand, the $10^{\text {th }}$ abdominal segment of females does not appear to be shorter than that of the co-generic species, since the same range of ratio values have 
been obtained. Additional male traits of systematic value, although tiny ones, are the flat, wide vomer base (Fig. 8E) followed by a decidedly narrower subsequent trait, and the short, acute cercus tooth: these traits, as far as we can judge, tell apart L. annaepaulae males from those of the remaining known taxa. In addition to the pink shadow, no additional morphological distinctions have been observed in females; even ootaxonomical characters have turned out not fully diagnostic, although rather well defined: L. annaepaulae lays long eggs with a high, positive opercular angle and ensuing low width:length ratios, but these same traits are also shared by L. caprai (Table 2). Therefore this species too appears to be a mix of more or less complete diagnostic features.

Holotype and paratype description. The body size of the male holotype is on the small side of the species range and has an overall striped appearance due to the sharply brown dorsal areas contrasting with the lateral white narrow lines and the cinnamon colour of the ventral body side. The brown colouration follows the generic pattern, with the two dorsal stripes just wider than usual to almost fuse each other on the median line on both the thorax and the abdomen. Eyes are light brown and almost pigment-less in their anterior half. The left hind femur presents a minute thorn, whereas all other leg segments are smooth. The sub-genital operculum has standard shape and size; its posterior rim is gently notched. The subanal vomer clearly shows the specific flat base, decidedly wider than the caudal part of it. Also the branching cercus tooth, covered with black hairs, has a fairly typical short and pointed appearance. The notching of the last tergite - the only one provided with a faint median carena - is shallow and narrow, affecting just one third of the tergite border.

The female paratype is average for body size and, at present, appears of a uniform light canella colour, since its native pink shadow has faded out in ethanol (compare to Fig. 6); limited light-brown areas can be perceived on the genae, pronotum and $2^{\text {nd }}$ abdominal tergite. The serrated series of lateral thoracic teeth is conspicuous; all legs are muticous. We here like to remind the main terminalia features of females, such as the ovipositor ventral valve tip - covered with black hairs - just shorter than the $1^{\text {st }}$ and $2^{\text {nd }}$ valve pairs, the soft last tergite uncovering the supra-anal valve and the straight protruding cerci (refer to Fig. 8G). Both holotype and paratype are housed in the Museo dell'Evoluzione of Bologna University, with collection numbers Gra096 anb Gra092, respectively.

Derivatio nominis. The species is dedicated to the distinguished Italian student of circum-Mediterranean stick-insects Anna Paola Bianchi, of Rome University La Sapienza, who first pointed out the occurrence of this southern Spanish Leptynia taxon with the same chromosome number as L. caprai, but with a clearly differing karyotype structure for some large pairs of the set (Bianchi, 1992).

We now try summarizing the more or less complete diagnoses made possible by the here analyzed characters (Table 5). It can be seen that: in the males the ratio of abdominal tergite $10^{\text {th }} v s$ the $9^{\text {th }}$ is fully diagnostic for L. annaepaulae as compared to all species and subspecies, while in L. attenuata it is diagnostic against the other species but not between L. attenuata subspecies. Among the latter, L. attenuata algarvica appears to be the most characterized, since its length of metanotum and median or hind femur are diagnostic $v s$ most of the other taxa (Table 5). On the other hand, the reach of the female hind femur is fully diagnostic for $L$. attenuata algarvica and almost completely so when each other taxon is considered. Egg parameters are very similar in L. annaepaulae and $L$. caprai, but fully diagnostic when the two are compared to all other taxa.

On the whole, it could be concluded that taking into account the whole series of the here reported qualitative and quantitative traits (in addition to karyotype) a reasonably safe identification of Leptynia taxa can be reached. 
Table 4. Holotype and paratype parameters and characterizing features of Leptynia attenuata subspecies and L. annaepaulae sp. n. Body length (in $\mathrm{mm}$ ) does not include antennae and cerci. * $=$ reference male of our collection; $\mathrm{h}=$ holotype, male; $\mathrm{p}=$ paratype, male for L. attenuata attenuata, female for L. annaepaulae; $\mathrm{R}=$ right; $\mathrm{L}=$ left. In the 'hind femur reach' column the ordinal refer to abdominal tergites.

\begin{tabular}{|c|c|c|c|c|c|c|}
\hline Taxon & $\begin{array}{l}\text { Body } \\
\text { length }\end{array}$ & $\begin{array}{l}\text { Antennal } \\
\text { articles }\end{array}$ & $\begin{array}{l}\text { Hind femur } \\
\text { reach }\end{array}$ & $\begin{array}{l}\text { Vomer } \\
\text { base }\end{array}$ & $\begin{array}{l}\text { Cercus tooth } \\
\text { features }\end{array}$ & Body colour \\
\hline L. a. attenuata $(*)$ & 43.5 & R15-15L & $7^{\text {th }}+1 / 2$ & swollen & slender, medium & brown/light canella \\
\hline L.a.iberica $(\mathrm{h})$ & 44.0 & R16-16L & $8^{\text {th }}+1 / 3$ & intermediate & wide base, short & brown/light canella \\
\hline L.a.algarvica $(\mathrm{h})$ & 40.0 & R16-16L & $6^{\text {th }}+1 / 2$ & swollen & stout, long & brown/light canella \\
\hline L. annaepaulae (h) & 42.0 & R16-16L & $7^{\text {th }}+3 / 4$ & flat & slender, pointed, short & dark brown/light canella \\
\hline L. annaepaulae (p) & 56.0 & R15-15L & $6^{\text {th }}+1 / 2$ & - & - & light pink/dark canella \\
\hline
\end{tabular}

Table 5. Diagnostic value of analyzed metric traits of Leptynia. The bold character indicates the compared taxon. $+=$ diagnostic trait; $\mathrm{o}=$ not diagnostic trait.

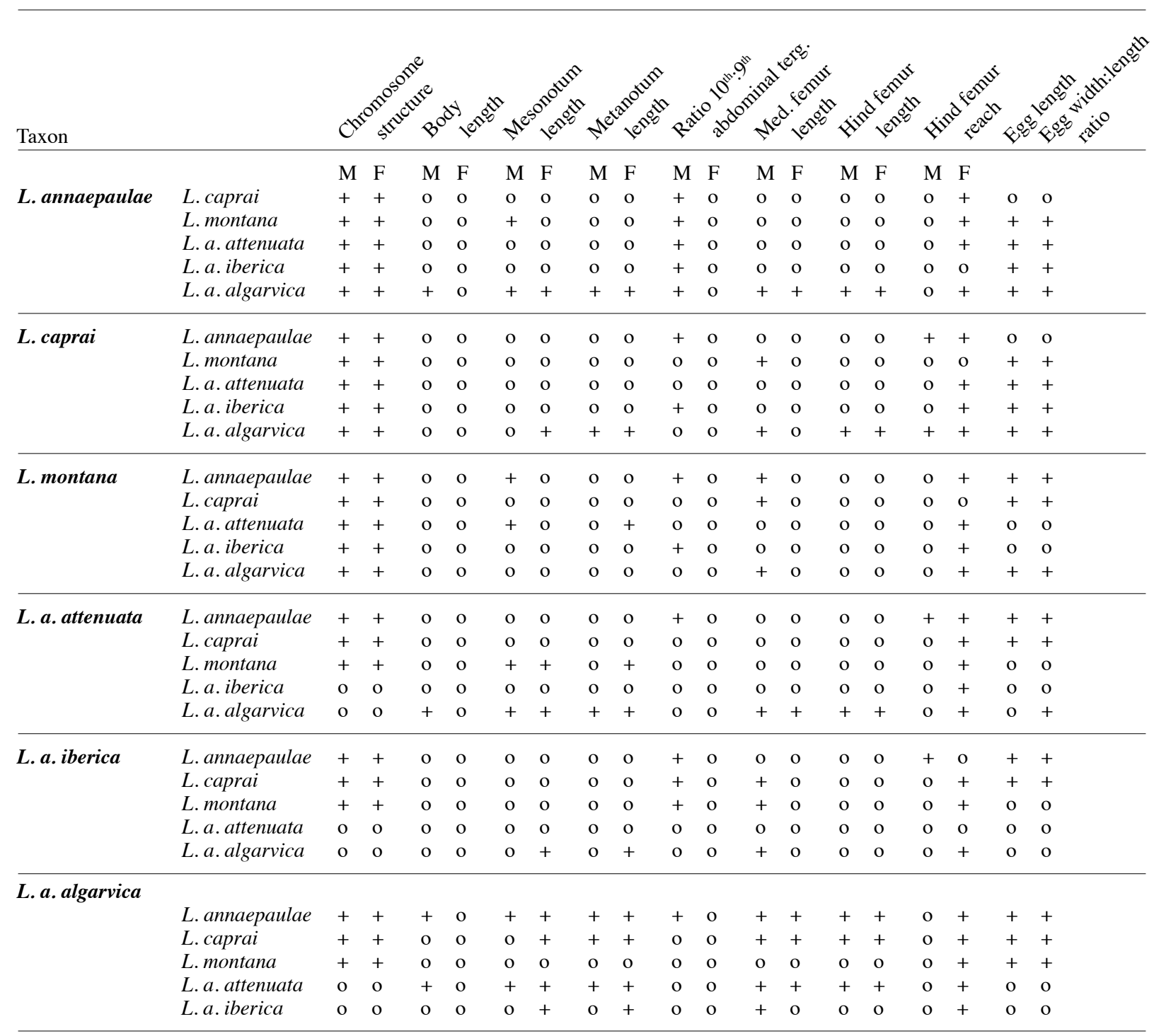

